\title{
Transformasi Bentuk Pertunjukan Ronggeng Pasaman Grup Ganto Saroha Kecamatan Duo Koto Kabupaten Pasaman
}

\author{
Kurniawan Fernando $^{1)}$, Martarosa $^{2)}$, Awerman ${ }^{3)}$ \\ ${ }^{12) 3)}$ Program Pascasarjana ISI Padangpanjang \\ Jl. Bahder Johan Guguk Malintang, Padang Panjang-Kota Padang Panjang, Sumatera Barat 27118 \\ Email: apardi44@gmail.com ${ }^{1)}$, martarosa@yahoo.com ${ }^{2)}$, rafilosa@yahoo.com ${ }^{3)}$
}

\begin{abstract}
This study aims to determine the transformation of the Ronggeng Pasaman performance of the Ganto Saroha group in Duo Koto District, Pasaman Regency. Ronggeng Pasaman is a performance art consisting of pantun, joget, and music, especially in Simpang Tonang, Pasaman, West Sumatra. The form of the Ronggeng Pasaman show is combining bouncing skills while dancing to the accompaniment of violin and drum music. The show starts at night, and ends until early morning. Currently Ronggeng Pasaman has undergone a transformation, people, especially young people, are less interested and begin to leave their regional arts, so the Ronggeng Pasaman show is rarely displayed. There was anxiety from the artists themselves, then initiatives emerged to attract the attention of the people. So it formed the Ronggeng Pasaman Ganto Saroha group, with the addition of keyboard music instruments in the show. Unlike the Pasaman Ronggeng Performance in general, the Ganto Saroha group does not show male singers with female appearance, but rather singers are real women or men. This study uses qualitative methods, is analytic description, observant participants. The results showed that the transformation carried out by the artists, made the Ronggeng Pasaman performance of the Ganto Saroha group well received and in great demand by all people in Pasaman, and was fully supported by the local government.
\end{abstract}

Keywords : Form Transformation, Pasaman Ronggeng Performance, Ganto Saroha Group

\begin{abstract}
Abstrak
Penelitian ini bertujuan untuk mengetahui transformasi bentuk pertunjukan Ronggeng Pasaman grup Ganto Saroha di Kecamatan Duo Koto, Kabupaten Pasaman. Ronggeng Pasaman merupakan seni pertunjukan terdiri dari pantun, joget, dan musik, khususnya terdapat di Simpang Tonang, Pasaman, Sumatera Barat. Bentuk pertunjukan Ronggeng Pasaman adalah menggabungkan keahlian berpantun sambil menari dengan iringan musik biola dan gendang. Pertunjukan dimulai pada malam hari, dan berakhir hingga menjelang pagi. Saat ini Ronggeng Pasaman telah mengalami transformasi, masyarakat khususnya anak muda kurang meminati dan mulai meninggalkan kesenian daerahnya, sehingga pertunjukan Ronggeng Pasaman jarang ditampilkan. Terdapat keresahan dari diri seniman, kemudian muncul inisiatif untuk menarik kembali perhatian masyarakatnya. Sehingga dibentuk grup Ronggeng Pasaman Ganto Saroha, dengan penambahan instrument musik keyboard dalam pertunjukannya. Beda dengan Pertunjukan Ronggeng Pasaman pada umumnya, grup Ganto Saroha tidak menampilkan penyanyi laki-laki berpenampilan perempuan, melainkan penyanyi adalah perempuan atau laki-laki sesungguhnya. Penelitian ini menggunakan metode kualitatif, bersifat deskripsi analitik, partisipan observan. Hasil penelitian menunjukkan bahwa transformasi yang dilakukkan para seniman, membuat pertunjukan Ronggeng Pasaman grup Ganto Saroha diterima dengan baik dan diminati semua kalangan masyarakat Pasaman, dan didukung penuh oleh pemerintahan setempat.
\end{abstract}

Kata kunci : Transformasi Bentuk, Pertunjukan Ronggeng Pasaman, Grup Ganto Saroha 


\section{Pendahuluan}

Kabupaten Pasaman merupakan salah satu wilayah yang terdapat di Provinsi Sumatera Barat. Penduduk Kabupaten Pasaman terdiri dari suku Minangkabau, suku Mandailing dari Sumatera Utara, dan suku Jawa. Pada masa pemerintahan Belanda, saat itu wilayah Pasaman mengikuti kebijakan pemerintahnya yaitu, wilayah Residentie van Sumatra Westkust. Setelah Indonesia merdeka wilayah Residentie van Sumatra Westkust dikenal sebagai provinsi Sumatera Barat, yang berbatasan dengan Sumatera Utara (Samad, 2002: 103).

Kabupaten Pasaman terdapat sebuah kesenian, dimana masyarakat tersebut menyebutnya dengan istilah Ronggeng Pasaman. Ronggeng Pasaman merupakan seni pertunjukan terdiri dari pantun, tari atau joget, dan musik. Khususnya terdapat di daerah Simpang Empat dan Simpang Tonang, Pasaman, Sumatera Barat (Takari, 2014: 61).

Bentuk pertunjukan Ronggeng Pasaman adalah menggabungkan keahlian berpantun sambil menari dengan iringan musik. Ronggeng Pasaman fungsi utamanya adalah hiburan atau sebagai pelipur lara. Ronggeng Pasaman biasanya dipertunjukkan pada malam hari, dimulai pukul sepuluh malam hingga menjelang subuh sekitar pukul lima pagi.

Tempat pertunjukan biasanya di lapangan terbuka atau di pentas yang dibuat khusus. Kesenian Ronggeng Pasaman ini biasanya dipertunjukkan dalam perhelatan perkawinan, perayaan hari kemerdekaan Indonesia, dan peringatan keagamaan Islam, seperti hari Raya Idul Fitri dan Idul Adha.

Pantun sebagai unsur penting dalam pertunjukan ini, didendangkan atau dinyanyikan oleh seorang penampil wanita atau anak Ronggeng sambil berjoget mengikuti irama lagu. Penyebutan kata anak Ronggeng mengacu pada pengertian, yaitu sebutan untuk penyanyi (penampil) wanita yang ahli dalam berpantun. Meskipun disebutkan ada penampil wanita atau anak Ronggeng, namun dalam kenyataannya para penampil tersebut semuanya adalah laki-laki. Untuk penampil atau penyanyi perempun, laki-laki tersebut didandani seperti perempuan dan memakai baju kurung.

Jenis pantun yang dibawakan adalah pantun mudamudi dinyanyikan mengikuti irama lagu, seperti lagu Cerai kasih, Kaparinyo, Buah Sempaya, Tari Payung, Mainang, Alah Sayang, Sinambang dan Si Kambang Baruih. Pantun-pantun yang didendangkan itu bersifat bebas dan lepas, tidak membentuk suatu kesatuan cerita. Pemain musik dalam tradisi Ronggeng Pasaman terdiri dari lima orang: satu orang menggesek biola, dua orang memukul gendang, satu orang memukul tamborin, dan satu orang memukul botol untuk menjaga tempo.

Pertunjukan Ronggeng Pasaman saat ini telah mengalami transformasi, mengapa terjadi transformasi ? mungkin masyarakat sudah mulai bosan karena pertunjukan Ronggeng Pasaman yang saat itu sangat monoton dan tidak mengikuti perkembangan zaman, seperti pada pertunjukan musik orgen tunggal misalnya, yang mana menampilkan penyanyi-penyanyi yang menarik dan pilihan lagu atau genre musik yang beragam, sehingga Ronggeng Pasaman kurang diminati dan mulai ditinggalkan anak mudanya. Terdapat keresahan dari diri seniman, sehingga munculnya inisiatif dari seniman tersebut untuk mencari warna baru yang lain, guna untuk menarik kembali perhatian masyarakat dalam menikmati pertunjukan Ronggeng Pasaman.

Saat ini terdapat grup Ronggeng Pasaman, grup tersebut bernama Ganto Saroha. Dalam pertunjukan tersebut grup Ganto Saroha tidak menggunakan anak Ronggeng, yaitu penyanyi laki-laki yang didandani seperti perempuan (Transvesti), namun penyanyi tersebut digantikan menjadi penyanyi perempuan atau laki-laki sebenarnya, artinya tidak terjadi Transvesti.

Dengan kemajuan teknologi saat ini dimanfaatkan oleh para seniman dari grup Ganto Saroha, yaitu dengan menambahkan instrument musik keyboard dan mengkolaborasikannya dengan instrument musik tradisi seperti biola dan gendang kedalam pertunjukan musik Ronggeng Pasaman, tentunya nuansa musik Ronggeng Pasaman grup Ganto Saroha menjadi sangat berbeda dibandingkan pertunjukan Ronggeng Pasaman lainnya.

Kenyataannya masyarakat di Kecamatan Duo Koto Kabupaten Pasaman sangat antusias dengan hadirnya grup Ganto Saroha. Adanya antusias dari masyarakat tersebut dan banyaknya minat masyarakat dalam menyaksikan pertunjukan Ronggeng Pasaman grup Ganto Saroha, akhirnya grup Ganto Saroha membuat kompilasi album Ronggeng Pasaman, dimana lagu-lagu tradisi Ronggeng Pasaman di aransemen ulang dan di rekam secara profesional di studio rekaman yang berada di daerah Talu, Pasaman pada tahun 2012.

Grup Ganto Saroha pada dasarnya telah mentransformasikan Ronggeng Pasaman dalam pertunjukan musiknya, seperti dengan penambahan alat musik keyboard, tidak menampilkan penyanyi laki-laki berpenampilan perempuan (Transvesti), penggunaan pengeras suara atau sound system (mixer \& amplifier) dan memasuki dunia rekaman dengan memiliki kaset cd berupa kompilasi album Ronggeng Pasaman yang di aransemen ulang.

Ketertarikan penulis di dalam pertunjukan Ronggeng Pasaman grup Ganto Saroha ini yaitu, ketika permainan melodi biola tradisi dikolaborasikan dengan permainan keyboard, apakah terjadi semacam perbenturan pada nada-nada yang dimainkan oleh para pemain musik seperti permainan biola dengan permainan keyboard. Instrument keyboard dibuat dari pabrikan dengan perfect diatonis atau memiliki nada yang sangat lengkap, dibandingkan instrument biola yang memiliki keterbatasan atau jangkauan pada bunyi nada. Lalu bagaimana dalam pertunjukan musiknya, apakah terjadi semacam kejar mengejar bunyi-bunyi nada antara permainan biola dengan permainan keyboard atau sebaliknya. Bila ada, apakah ada toleransi antar pemain musik dalam pertunjukannya? Lalu bagaimana rasa daripada penonton dalam menikmati pertunjukan Ronggeng Pasaman grup Ganto Saroha? Adanya transformasi bentuk pertunjukan Ronggeng Pasaman 
grup Ganto Saroha dan keberadaannya telah berkembang di tengah-tengah masyarakat Kecamatan Duo Koto Kabupaten Pasaman, akan menjadi hal yang penting untuk diteliti lebih mendalam.

Penelitian transformasi pertunjukan Ronggeng Pasaman pada group Ganto Saroha di Andilan Nagari Simpang Tonang Kecamatan Duo Koto Kabupaten Pasaman ini menggunakan metode kualitatif dan deskriptif analisis dengan pendekatan multi-disiplin di bawah payung disiplin Musikologi. Metode penelitian kualitatif digunakan dalam penelitian ini karena data yang didapatkan tidak melalui prosedur statistik, melainkan didapatkan dari pengamatan pada manusia dalam kawasannya sendiri dan berhubungan dengan orang-orang tersebut dalam bahasanya dan dalam peristilahannya.

Penelitian ini menerapkan metode Alan P. Merriam mengenai tiga tahapan, yaitu: (1) mengumpulkan data; (2) memilahnya kepada dua jenis analisis yakni (a) menelaah bahan-bahan Etnografi dan Etnologi yang dikumpulkan dengan cara mengkaji secara ilmiah dan rasional mengenai praktik musik, perilaku, dan konsepkonsep dalam masyarakat untuk melihat apakah sesuai dengan hipotesis dan rancangan awal, (b) analisis laboratorium terhadap bahan-bahan musik yang telah dikumpulkan, hal ini menuntut teknik dan terkadang alat bantu khusus dalam membuat transkrip dan analisis struktur musiknya; dan (3) data yang sudah dianalisis dan hasil yang sudah didapat diterapkan kembali pada masalah terkait, khususnya dalam musikologi dan lebih luas lagi dalam ilmu pengetahuan sosial dan humaniora (Merriam, 1964 :7). Selain itu, penelitian ini juga dilakukan dengan kerterlibatan langsung penulis pada proses pertunjukan musik, serta proses kehidupan seharihari masyarakat Andilan Duo Koto Pasaman.

\section{Pembahasan}

Ganto Saroha adalah grup Ronggeng Pasaman yang sudah berubah dan berbeda dengan pertunjukan grup Ronggeng Pasaman lainnya yang berada di Pasaman. Grup Ronggeng Ganto Saroha ini berdiri pada tahun 2011 di Andilan Nagari Simpang Tonang Kecamatan Duo Koto Kabupaten Pasaman. Grup Ronggeng Ganto Saroha ini sering tampil di berbagai acara, seperti pada acara peringatan keagamaan Islam yaitu hari raya Idul Fitri dan Idul Adha, pada pesta pernikahan, dan pada acara-acara lainnya. Bukan hanya pertunjukan di daerah Pasaman saja, tetapi grup Ganto Saroha juga melakukan pertunjukan di luar kota, seperti di kota Medan, Padang, Bukittinggi, Batam.

Grup Ronggeng Ganto Saroha ini diteliti dengan pendekekatan transformasi. Dalam hal ini Heddy Shri Ahimsa-Putra dalam Strukturalisme Levi Strauss Mitos dan Karya Sastra menjelaskan apa itu transformasi. Transformasi menunjuk pada berubahnya sesuatu tetapi (seolah-olah) tanpa melalui sebuah proses, atau proses tersebut tidak dipandang penting. Dalam suatu transformasi yang berlangsung adalah sebuah perubahan pada tataran permukaan, sedang pada tataran yang lebih dalam lagi perubahan tersebut tidak terjadi. (Ahimsa, $2006: 61)$.

Senada dengan pemikiran Ahimsa, berkaitan dengan penelitian Ronggeng Pasaman grup Ganto Saroha, permasalahan yang diungkap dengan pendekatan transformasi. Ada tiga aspek didalam melihat transformasi yang penulis amati, yaitu dilihat dari aspek bentuk, yaitu bentuk yang sudah berubah, kemudian fungsi, dimana dampak dari perubahan bentuk tersebut akan berpengaruh kepada fungsinya, dan dari dampak perubahan bentuk dan fungsi tersebut akan berpengaruh kepada nilai.

\section{A. Bentuk}

Dimana sebelumnya pertunjukan Ronggeng Pasaman hanya menggunakan instrument biola sebagai pembawa melodi yang mengiringi sipenyanyi dalam berpantun. Namun grup Ganto Saroha menambah instrument keyboard dan mengkolaborasikannya dengan instrument biola dan gendang. Selain itu pertunjukan Ronggeng Pasaman biasanya menghadirkan anak Ronggeng atau penyanyi laki-laki yang didandani seperti perempuan (transvesti), pada pertunjukan Ronggeng Pasaman grup Ganto Saroha anak Ronggeng tersebut berubah menjadi penyanyi laki-laki dan perempuan yang sebenarnya, artinya penyanyi dalam pertunjukan Ronggeng Pasaman grup Ganto Saroha tidak transvesti. Selain itu grup Ganto Saroha menggunakan sound system seperti, monitor, amplifier dan mixer tentunya dengan penggunaan sound system tersebut akan menghasilkan bunyi musik yang lebih kuat, tentunya berbeda dengan pertunjukan Ronggeng Pasaman sebelumnya atau tradisi, yang hanya menggunakan pengeras suara Toa.

\section{B. Fungsi}

Transformasi bentuk yang terjadi pada pertunjukan Ronggeng Pasaman grup Ganto Saroha, juga berdampak kepada fungsi, dimana dalam pertunjukan Ronggeng Pasaman grup Ganto Saroha tidak hanya membawakan lagu-lagu (tradisi) Ronggeng Pasaman, tetapi juga memainkan lagu-lagu pop, dangdut, dll. Tentunya lagulagu yang dimainkan tersebut sesuai dengan permintaan dari penonton. Artinya grup Ganto Saroha berbeda dengan grup Ronggeng Pasaman (tradisi) pada umumnya, dimana dalam durasi pertunjukannya dari awal pertunjukan hingga akhir pertunjukannya hanya membawakan lagu-lagu tradisi saja.

\section{Nilai}

Dampak dari sebuah transformasi mengakibat kepada berubahnya bentuk, kemudian berdampak kepada fungsi. Dampak dari perubahan bentuk dan fungsi tersebut juga berpengaruh kepada nilai, nilai yang dimaksud adalah pada nilai ekonomis, dimana grup Ganto Saroha memiliki tarif untuk mendatangkannya. Tarif tersebut memiliki standar, seperti jauh dan dekatnya jarak tempuh lokasi pertunjukan, atau pertunjukan di dalam kota/daerah, atau diluar kota/daerah. Berbeda dengan mendatangkan grup Ronggeng tradisi, dimana grup tersebut hanya di jemput, kemudian disela istirahat 
pertunjukan diberi makan, minum dan diberi rokok, kemudian di akhir pertunjukannya grup tersebut diantarkan pulang kembali. Artinya grup atau seniman tradisi pada pertunjukan Ronggeng Pasaman yang berada di Kecamatan Duo Koto tersebut tidak membuat tarif untuk mendatangkannya.

Penulis dalam kajian ini, menggunakan Performance Theory atau teori pertunjukan untuk membahas pertunjukan Ronggeng Pasaman grup Ganto Saroha. Pertunjukan menurut Schechner merupakan tindakan yang dikerangkakan, disajikan atau dipertontonkan untuk orang lain, dan tindakan-tindakan itu merupakan gagasan yang mendasari dari pertunjukan. Tindakan atau wujud perilaku yang disajikan dalam pertunjukan merupakan kualitas perilaku yang diperbaiki atau direstorasi. Artinya, yang ditampilkan bukanlah suatu yang biasa dan bersifat keseharian, tetapi bersifat luar biasa atau telah mengalami perestorasian atau perbaikan perilaku keseharian Schechner dalam bukunya Performance Theory menjelaskan struktur dasar pertunjukan, pengelompokkan aktivitas manusia yang termasuk dalam pertunjukan, dan yang lebih khusus juga membahas bagian penting dari pertunjukan. Struktur dasar pertunjukan terdiri atas tiga tahap, yaitu: persiapan, pertunjukan, dan aftermath (Schechner dalam Asril 2016: 31).

Persiapan meliputi pemusik mempersiapkan diri untuk latihan, sedangkan penonton mempersiapkan diri untuk menonton pertunjukan Ronggeng Pasaman. Pertunjukan merupakan peristiwa pemusik dari grup Ronggeng Pasaman melakukan pementasan dan penonton menyaksikan pertunjukan Ronggeng Pasaman. Aftermath meliputi istirahat pemusik dari grup setelah usai bermain musik, serta membereskan peralatan dan instrument musik grup tersebut.

\section{Persiapan}

Persiapan pertunjukan dari grup Ronggeng Pasaman meliputi latihan rutin yaitu pada malam hari senin, selasa dan rabu malam. Latihan bertempat di rumah salah satu pemusik, tempat yang sudah dibuat khusus untuk latihan musik bersama. Sebelum latihan bersama, biasanya pemusik berkumbul berdiskusi bersama menceritakan kehidupan sosial keluarga, dan pekerjaan masingmasing. Diskusi bersifat santai, saling bertanya dan menjawab sesama pemusik. Diskusi tersebut membuat hubungan emosional semakin dekat, terbuka, saling pengertian yang menciptakan suasana kekeluargaan sesama pemusik.

Latihan musik disesuaikan dengan posisi keahlian masing-masing pemusik terhadap instrumennya. Pemusik terdiri dari beberapa orang pemain, yaitu satu orang pemain keyboard untuk pertunjukan Ronggeng Pasaman yang modern, satu orang pemain biola, satu orang pemain gendang, dan beberapa penyanyi. Ketika pemain musik sudah lengkap, maka pemain musik memiliki kesadaran masing-masing untuk mempersiapkan instrumen musik beserta pengeras suara yang telah disediakan. Setelah semua instrumen musik ditata sesuai kebutuhan pemusik.
Pada awal pertunjukan Ronggeng Pasaman, ada bagian musik solo yaitu suling dan bagian dendang yang dinyanyikan penyanyi laki-laki. pemain musik suling yang akan menjadi pembuka atau mengawali pertunjukan musik dengan mengiringi alunan vokal tradisi yang didendangkan oleh penyanyi. Setelah selesai memainkan musik untuk pembukaan, maka pemusik mulai memainkan lagu-lagu tradisi Ronggeng Pasaman. Lagu-lagu tradisi Ronggeng Pasaman yang dilatih untuk dibawakan saat pertunjukan atau pementasan nantinya, diantaranya yaitu lagu; Ka Guo, Bio-bio, Rosmali, Sikambang Rang Jauah, Aliatun, Sikambang Simpang Tonang, Bateh Tontong, Kaparinyo Padang, Ta Ijo Ijo, Anak Dagang, Filosofi Incir Aek, Mainang Sibolga dan Talak Tigo. Susunan latihan yaitu dengan menyelasaikan satu lagu, kemudian dilanjutkan dengan melatih lagu lainnya, tentunya lagu yang dilatih lainnya melalui kesepakatan antara pemain musik dengan penyanyi.

Fungsi dari latihan yaitu untuk meyamakan rasa musikal sesama pemusik, dan persiapan untuk pementasan-pementasan berikutnya. Dengan seringnya berlatih bersama, pemusik meyakini bahwa permainan musik yang akan ditampilkan akan semakin kompak, rapi dan enak didengar.

\section{Pertunjukan}

Untuk mendapatkan permainan yang pas, sesama anggota grup mencari pemain musik yang peka terhadap bunyi nada ataupun melodi dalam bermain musik bersama. Dalam pertunjukan Ronggeng Pasaman yang sudah modern misalnya, ada sedikitnya dari tiga pemain biola bisa bermain bersama dan bisa memainkan atau menebak melodi untuk biola yang dimainkan dengan akord pada instrumen keyboard. Setelah menetapkan pemain musik biola yang pas untuk berkolaborasi dengan keyboard, maka dilakukan proses latihan bersama. Seiring berjalannya waktu dan seringnya melakukan pertunjukan, masing-masing individu sudah memahami karakter dari cara bermain musik sesama pemusik. Sehingga pemusik tidak mengalami permasalahan dalam permainan musik bersama.

Pertunjukan Ronggeng Pasaman biasanya bertepatan di saat hari libur atau di saat acara-acara tertentu. Pertunjukan Ronggeng Pasaman dipertunjukkan dalam peringatan keagamaan Islam, seperti hari Raya Idul Fitri dan Idul Adha, perhelatan perkawinan, perayaan hari kemerdekaan Indonesia, dan acara dalam undangan pemerintahan.

Pertunjukan Ronggeng Pasaman dipertunjukkan pada malam hari, dimulai pukul delapan malam hingga menjelang subuh sekitar pukul lima pagi. Persiapan yang dilakukan sebelum pertunjukan yaitu, gotong royong sesama pemusik mengangkat sound system dan perlengkapan alat musik naik ke atas mobil yang sudah disiapkan dan dibawa kelokasi atau tempat pertunjukan yang telah disediakan warga masyarakat yang mengundang. Setibanya dilokasi atau tempat pertunjukan, dilakukan pemasangan alat baik itu alat musik maupun sound system, dengan menyesuaikan besar atau kecilnya pentas pertunjukan yang sudah 
disediakan warga masyarakat. Setelah melakukan pemasangan alat, maka dilakukan pengecekan bunyi sound system, kemudian pengesetan instrumen musik sesuai dengan formasi masing-masing pemusik. Setelah memastikan bunyi sound system dan instrument musik enak didengar, maka pertunjukan Ronggeng Pasaman akan dimulai.

Pada awal pertunjukan Ronggeng Pasaman, ada bagian musik solo yaitu suling dan bagian dendang yang dinyanyikan penyanyi laki-laki. Pemain musik suling menjadi pembukak atau mengawali pertunjukan musik dengan mengiringi alunan vocal tradisi yang didendangkan oleh sipenyanyi. Setelah selesai memainkan musik untuk pembukaan, pembawa acara memberi kata pembukaan dengan memberi sambutan selamat datang kepada penonton pertunjukan yang datang. Ketika sambutan untuk pembukaan telah dilakukan, maka instrumen musik dimainkan, musik yang dimainkan merupakan bagian intro musik dari salah satu lagu tradisi Ronggeng Pasaman yang akan dimainkan nantinya, bagian intro musik hanya dimainkan oleh pemain musik saja, tanpa ada suara vocal. Salah satu pemusik mengajak pemusik lainnya bermain musik menikmatinya dengan santai. Ketika situasi bermain musik dengan santai ini menciptakan suasana keakraban, kekeluargaan sesama pemain musik. Sesekali pujian sesama pemain musik terucap, karena merasakan kepuasan dengan intrumen musik yang memainkan musik-musik tradisi Ronggeng Pasaman. Pada bagian kedua, pemusik memainkan beberapa lagu tradisi Ronggeng Pasaman berduet antara penyanyi lakilaki dan penyanyi perempuan. Suasana pun semakin ramai, tempo permainan sudah mulai cepat. Terlihat dari ekspresi para penonton yang menyaksikan pertunjukan bersemangat, antusias, canda tawa, serta penonton pun ingin ikut berjoget naik ke atas pentas pertunjukan. Panitia acara menyediakan kursi untuk penonton dalam menikmati pertunjukan musik, namun banyak juga penonton yang tidak kedapatan kursi dan akhirnya memilih untuk berdiri.

Pertunjukan Ronggeng Pasaman memiliki aturan saat di atas pentas atau panggung pertunjukan, seperti membatasi penonton yang ingin bernyanyi sambil berbalas pantun, berjoget bersama penyanyi. Tentunya aturan tersebut dibuat demi kelancaran pertunjukan. Ketika pertunjukan musik sedang berlangsung, sebagian penonton ikut berjoget bersama penonton lainnya berjoget didepan panggung pertunjukan, sesekali ada penonton yang usil naik ke atas pentas pertunjukan, awalnya satu penonton saja yang naik untuk berjoget bersama penyanyi, lama kelamaan menyusul penonton lainnya naik keatas panggung pertunjukan. Pembawa acara sangat diperlukan dalam pertunjukan Ronggeng Pasaman, disini pembawa acara harus cakap berinteraksi dengan penonton pertunjukan. Pembawa acara juga harus bisa mengendalikan penonton yang melanggar atau mengganggu kelancaran di saat pertunjukan musik sedang berlangsung. Naik turunnya kemeriahan dan kualitas acara ditentukan oleh interaksi pembawa acara baik dengan pemain musik, penyanyi, maupun masyarakat yang sedang menonton pertunjukan. Senada dengan itu Rosa menyatakan sebagai berikut.

"Pembawa acara dalam pertunjukan Ronggeng Pasaman sangat diperlukan sekali, karna sebagai pembawa acara saya bisa menjembatani interaksi sesama penonton maupun pemusik. Saya sebagai pembawa acara harus peka terhadap penonton, banyak tipe penonton dalam menikmati pertunjukan Ronggeng Pasaman, diantaranya penonton yang biasanya anak muda yang sedang mabuk selepas meneguk minuman keras atau alkohol dan membuat kerusuhan atau kegaduhan dengan penonton yang lainnya, disini peran saya sebagai pembawa acara yang akan menanganinya. Biasanya cara saya menangani penonton yang rusuh yaitu dengan cara menghampirinya dan mengajak mereka bernyanyi ataupun berjoget bersama, dan seketika penonton yang rusuh tadi pun menjadi tenang, disaat itu saya menasehati mereka dengan menggunakan bahasa yang tidak menyinggung. Terbukti selama pertunjukan Ronggeng Pasaman berlangsung, penonton menikmati pertunjukan dengan tertib hingga sampai akhir pertunjukan selesa". (Wawancara: Rosa, di Simpang Tonang, Kecamatan Duo Koto, Kabupaten Pasaman, 2018).

Pada pertunjukan Ronggeng Pasaman juga terjadi persaingan, persaingan yang dimaksud yaitu aksi berbalas pantun di atas pentas pertunjukan antara penyanyi dari grup dengan penyanyi yang berasal dari penonton. Penonton dalam hal ini dilibatkan dalam pertunjukan. Adapun aksi berbalas pantun tersebut, yaitu dimana penyanyi yang berasal dari penonton tersebut dengan lirik pantun yang dinyanyikan merayu penyanyi perempuan dari grup, dan rayuan tersebut juga dibalas dengan spontan oleh penyanyi perempuan dari grup tersebut. Ketika aksi berbalas pantun antara penyanyi dari grup dengan penyanyi dari penonton tersebut, membuat suasana pertunjukan menjadi meriah dan heboh dengan tepuk tangan dan teriakan dari pemusik maupun penonton pertunjukan, terkadang hal ini membuat penonton lainnya ikut serta dalam pertunjukan untuk berbalas pantun dengan penyanyi dari grup tersebut dan ada juga penonton yang ikut naik ke atas pentas pertunjukan hanya untuk ikut berjoged bersama. Pedagang sangat banyak ditemukan di saat pertunjukan Ronggeng Pasaman berlangsung, pedagang memanfaatkan moment ini untuk meraih keuntungan dengan cara berjualan. Adapun pedagang terdiri dari penjual makanan, minuman, jajanan khas tradisional, mainan anak-anak, dan bahkan ada juga yang menjual pakaian.

\section{a. Aftermarth}

Aftermarth ialah kegiatan yang dilakukan setelah pertunjukan (Schechner dalam Asril, 2016: 218). Pada bagian ketiga ini yaitu kegiatan mengembalikan kembali instrumen musik dan sound system atau pengeras suara pada tempat penyimpanan di rumah Ijal. Aktivitas pengembalian instrumen musik dilakukan melalui kesadaran tiap pemusik. Rasa saling memiliki terhadap 
instrumen musik terlihat dari cara memainkan dan merawatnya dengan cara membersihkan debu atau kotoran yang menempel pada instrumen tersebut. Dengan adanya rasa saling memiliki diantara sesama pemusik, maka terwujudlah rasa kebersamaan, solidaritas, saling mengerti, dan rasa kekeluargaan.

Setelah selesai dari aktivitas pengembalian alat-alat dan instrumen yang digunakaan saat pertunjukan secara bergotong royong menyimpannya kerumah atau studio, biasanya para pemusik melakukan diskusi evaluasi diteras rumah dari ketua kelompok. Diskusi tersebut biasanya membahas apa saja kekurangan atau hal-hal yang dialami selama pertunjukan berlangsung, seperti pembahasan aransemen permaianan musik, kostum, skenario pantun yang akan dinyanyikan. Tentunya diskusi ini ialah untuk mengevaluasi apa-apa saja kekurangan-kekurangan yang didapat saat pertunjukan dan mencari solusi bersama-sama guna untuk kemajuan grup. Biasanya diskusi berakhir dengan canda, tawa sesama pemusik selepas penat melakukan pertunjukan bersama. Kemudian dilakukan pembagian honor dan disesuaikan dengan bayaran dari yang mengundang.

Untuk meningkatkan pemahaman pada objek penelitian bentuk seni pertunjukan Ronggeng Pasaman di Kabupaten Pasaman Sumatera Barat, salah satu langkah penting yang harus di persiapkan dalam proses kajian terhadap permasalahan yang di teliti adalah mencari metode yang tepat serta efisien dalam pengumpulan data di lapangan. Penulis dalam kajian ini menggunakan metode penelitian di antara, Seperti yang diungkapkan Ruth T. Watanabe dalam bukunya Introduction to Music Research, menjelaskan beberapa metode penelitian dasar dalam musik;

(1) Perkembangannya, dimana proses evolusi subjek dipelajari; (2) Analisis, di mana subjek dipisahkan dan direkonstruksi untuk mempelajari mengapa dan bagaimana fungsinya; (3) Teoritis, dimana subjek terkait dengan konsep seperti bentuk, harmoni, tandingan, dan perangkat komposisi; (4) Komparatif, dimana beberapa elemen dapat diperiksa untuk titik kesamaan; dan sebaliknya, kontras, dimana titik perbedaan dicatat (Watanabe, 1967: 5).

Melalui empat metode penelitian musik Watanabe, maka pengetahuan dari seni pertunjukan Ronggeng Pasaman akan membantu penulis dalam mengkaji permasalahan. Yaitu dengan kehadiran seni pertunjukan Ronggeng Pasaman di tengah-tengah masyarakat Pasaman, menikmati pertunjukan Ronggeng Pasaman dalam bentuk tradisi dan modern.

Penelitian bentuk seni pertunjukan Ronggeng Pasaman di Kabupaten Pasaman Sumatera Barat ini dilakukan dengan keterlibatan langsung penulis dalam proses pertunjukannya. Seperti mengamati aktivitasaktivitas perilaku masyarakat Pasaman dalam menonton pertunjukan musik. Maka dari itu, penelitian ini menggunakan data primer, dan data sekunder, dan data pendukung dari lapangan.

Sumber data primer adalah pemusik pelaku utama pemusik Ronggeng Pasaman dalam pertunjukan, sementara data sekunder adalah penonton pertunjukan
Ronggeng Pasaman ketika pertunjukan sedang berlangsung, sementara data pendukung adalah tokoh masyarakat dan budayawan yang mengerti adat istiadat, untuk memberikan informasi mengenai masyarakat Kabupaten Pasaman Sumatera Barat. Metode penelitian kualitatif pengumpulan data dari lapangan dengan teknik pengamatan, keterlibatan, wawancara, perekaman audio visual, dan analisa data.

Lokasi penelitian Ronggeng Pasaman grup Ganto Saroha berada di Kecamatan Duo Koto Kabupaten Pasaman Sumatera Barat. Penelitan bentuk seni pertunjukan Ronggeng Pasaman di Kabupaten Pasaman Sumatera Barat ini dilakukan pada acara, seperti perhelatan perkawinan dan peringatan keagamaan Islam yaitu hari Raya Idul Fitri dan Idul Adha. Pertunjukan Ronggeng Pasaman dimulai pada malam hari sekitar pukul 19.00 WIB sampai menjelang pagi sekitar pukul $03.00 \mathrm{WIB}$.

Teori musikologi akan digunakan untuk menganalisis struktur bentuk musik Ronggeng Pasaman grup Ganto Saroha. Senada dengan Karl Edmund Prier mengatakan bahwa struktur musik dibangun dari adanya ritme, melodi, kalimat, dan bentuk. Karl Edmund Prier dalam bukunya Ilmu Bentuk Analisis (1988), mengatakan;

"Struktur lain yang menjadi komponen utama dalam musik ialah tangga nada (scale), nada dasar (pitch center), wilayah nada (range), jumlah nada, jumlah interval, pola cadence (cadence patterns), formula melodi, dan contur (contour)" (Prier, 1988 :52).

Selanjutnya Leon Stein dalam bukunya Structure Style The Study and Analysis of Musical Form (1969), mengatakan;

"Dalam menganalisis bentuk musik, yang dibahas adalah tentang figure, motif, semi frase, frase, periode, kombinasi kalimat" (Leon Stein, 1969 :110).

Teori musikologi dalam kajian ini bertujuan untuk menganalisa struktur bentuk musik pada lagu-lagu Ronggeng Pasaman yang sudah di aransemen ulang oleh grup Ganto Saroha. Dalam menganalisa struktur bentuk musik pada lagu-lagu Ronggeng Pasaman grup Ganto Saroha, penulis memilih salah satu lagu yang paling popoler dan sering dibawakan saat pertunjukan Ronggeng Pasaman grup Ganto Saroha, yaitu lagu Taijo Ijo. Jenis musik pada lagu Taijo Ijo ini adalah jenis musik monophonic, dimainkan dengan tangga nada $\mathrm{C}$ mayor, dengan metrum 2/4. Lagu Taijo Ijo ini merupakan lagu satu bagian yang terdiri dari 16 birama, 2 periode, dan masing-masing periode memiliki kadens yaitu Half Authentic Cadens (HAC) dilihat dari pergerakan akor pada setiap akhir kalimat lagu, yaitu dar akor I ke akor V. Dalam lagu Taijo Ijo ini melodi lagu menggunakan scale Pentatonik yang terdiri dari 5 nada yaitu Do Re Mi Sol La. Adapun instrument yang digunakan yaitu; vocal berperan sebagai pembawa syair dan melodi, biola berperan sebagai filler (pengisi kekosongan dalam musik) dan juga ikut membawakan 
melodi utama, keyboard berperan sebagai pengisi harmoni dan beberapa sound pada keyboard memainkan filler, gendang berperan sebagai pemberi ketukan, ritem dan fill-in pada pukulan gendang.

\section{Kesimpulan}

Transformasi dalam pertunjukan Ronggeng Pasaman grup Ganto Saroha pada masyarakatnya sangat diterima dengan baik, baik itu anak-anak, remaja, maupun orang tua. Grup Ganto Saroha dalam pertunjukannya menggunakan instrumen musik keyboard dan tidak menampilkan penyanyi atau Anak Ronggeng yang berpenampilan seperti perempuan dalam pertunjukannya, menjadi tontonan atau hiburan berupa pertunjukan baru bagi masyarakat Pasaman. Tentunya kemajuan teknologi saat ini dimanfaatkan grup Ganto Saroha, agar kesenian Ronggeng di Pasaman tetap hidup, berkembang dan terus dinikmati masyarakat. grup Ronggeng Ganto Saroha sudah mengikuti rekaman, rekaman tersebut sudah dua kali dilakukan. Saat ini grup Ronggeng Ganto Saroha sudah mempunyai dua album musik Ronggeng Pasaman, dua album tersebut diberi nama Ronggeng Kreatif Ganto Saroha. Album tersebut memuat lagu-lagu Ronggeng Pasaman pada umumnya, lagu-lagu tersebut di arransemen ulang, arransemen tersebut dengan menambahkan akord dan harmoni. Selain itu beberapa bunyi sound musik seperti, bunyi akordion dan bunyi sound instrument musik lainnya yang dihasilkan pada instrument keyboard tersebut.

\section{Daftar Pustaka}

Ahimsa-Putra, H.S. 2006, Strukturalisme Levi-Strauss Mitos dan Karya Sastra, $\quad$ Yogyakarta :KEPEL PRESS.

Asril. 2016, "Tabuik: Pertunjukan Budaya Hibrid Masyarakat Kota Pariaman Sumatra Barat". Disertasi. Yogyakarta: ISI.

Bonoe, Panoe. 2003, Kamus Musik, Yogyakarta: Kanisius.

Damono, Sapardi Djoko. 2012, Alih Wahana, Jakarta: Editum.

Edmund, Karl. 2015, Ilmu Bentuk Musik, Yogyakarta: Pusat Musik Liturgi.

Ganap, Victorius. 2006, "Krontjong Toegoe Sejarah Kehadiran Komunitas dan Musiknya di Kampung Tugu, Cilincing Jakarta Utara”. Disertasi Yogyakarta: UGM.

Koentjaraningrat. 1990, Pengantar Ilmu Antropolgi. Jakarta: Universitas Indonesia Press.

Liliweri, Alo. 2014, Pengantar Studi Kebudayaan. Bandung: Penerbit Nusa Media.

Martarosa, 2017, "Apropriasi Musik Oleh Masyarakat Bandar Pesisir Sumatera Barat”. Disertasi. Yogyakarta: UGM.

Martarosa, 2016, "The History And Development Of Gamat Music As A Prototype Of Bandar Art In The West Sumatera Coastal Area (Pesisir)". Jurnal. Yogyakarta: Humaniora.
Martarosa, 2016, "Apropriasi Musikal dan Estetika Musik Gamat”. Jurnal. Yogyakarta: Humaniora.

Merriam, Alan P. 1999, Terjemahan: Triyono Bramantyo. Antropologi Musik. Yogyakarta: Institut Seni Indonesia Yogyakarta.

Nelson, C., P.A. 1992, Treichler, and L. Grossberg. Cultural Studies. New York: Routledge.

P. Spradley, James. Edisi Kedua 2006, Metode Etnografi, Yogyakarta: Tiara Wacana.

Schecner, Richard. 2003, Performance Theory. London dan New York: Routledge.

Sutrisno, Mudji. 2005, Teori-Teori Kebudayaan. Yogyakarta: Kanisius.

Samad, Duski, dkk. 2002, Ensiklopedia Minangkabau. Jakarta: PT Rumpun Dian Nugraha dan Gebu Minang.

Sugiyono. 2008, Metode Penelitian Kualitatif, kualitatif dan $R \& D$. Bandung: alfabeta.

Soedarsono, R.M. 2001, Metode Penelitian Seni Pertunjukan dan Seni Rupa. Bandung: Masyarakat Seni Pertunjukan Indonesia.

Soedarsono, R.M. 1999, Seni Pertunjukan dan Pariwisata. Yogyakarta: BP ISI.

Stein, Leon. 1979, Structure \& Style the Study and Analysis of Musical Form. New Jersey: Summy-Birchard Music.

Simatupang, Lono. 2013, Pergelaran: Sebuah Mozaik Penelitian Seni-Budaya. Yogyakarta :Jalasutra.

Takari, Muhammad. 2014, Ronggeng dan Serampang Dua Belas dalam Kajian Ilmu-ilmu Seni. Medan :USU Press.

Watanabe, Ruth T. 1967, Introduction to Music Research.New Jersey: Prentice Hall.

\section{Data Narasumber}

Ayu, 28 tahun, Ibu rumah tangga, penyanyi grup Ganto Saroha, Alamat Andilan Nagari Simpang Tonang, Kecamatan Duo Koto, Kabupaten Pasaman, 28 juni 2017.

Adi, 47 tahun, Petani dan Pengrajin, pemain Biola grup Ganto Saroha, Alamat Andilan Nagari Simpang Tonang, Kecamatan Duo Koto, Kabupaten Pasaman, 28 juni 2017.

Edeh, 45 tahu, Petani, pemain suling grup Ganto Saroha, Alamat Andilan Nagari Simpang Tonang, Kecamatan Duo Koto, Kabupaten Pasaman, 28 juni 2017.

Ijal, 57 tahun, Pensiunan, Pimpinan dan Pendiri grup Ganto Saroha sekaligus Pemain Orgen/keyboard Ganto Saroha, Alamat Andilan Nagari Simpang Tonang, Kecamatan Duo Koto, Kabupaten Pasaman, 28 juni 2017.

Kiyet, 45 tahun, Petani, penyanyi laki-laki grup Ganto Saroha Alamat Andilan Nagari Simpang Tonang, Kecamatan Duo Koto, Kabupaten Pasaman, 28 juni 2017.

Patra, 36 tahun, Petani, pemain gendang grup Ganto Saroha, Alamat Andilan Nagari Simpang Tonang, 
Kecamatan Duo Koto, Kabupaten Pasaman, 28 juni 2017.

Rosa, 34 tahun, Guru, penyanyi grup Ganto Saroha, Alamat Andilan Nagari Simpang Tonang, Kecamatan Duo Koto, Kabupaten Pasaman, 28 juni 2017.

Sayus, 47 tahun, Petani, penyanyi laki-laki grup Ganto Saroha, Alamat Andilan Nagari Simpang Tonang, Kecamatan Duo Koto, Kabupaten Pasaman, 28 juni 2017. 